\title{
THE IMPORTANCE AND PRESENCE OF PROFESSIONAL VALUERS IN FINANCIAL REPORTING
}

\author{
Danijela Ilić ${ }^{1}$, Vule Mizdraković ${ }^{2}$ \\ ${ }^{1}$ National Association of Valuers of Serbia NAVS (NUPS), Belgrade, Serbia \\ ${ }^{2}$ Faculty of Business in Belgrade, Singidunum University, Belgrade, Serbia
}

\begin{abstract}
:
In this paper, we have emphasized the importance that the property valuation by professional valuers may have in the modern business, primarily in the financial reporting process. The introduction of International Financial Reporting Standards in the Republic of Serbia and the frequent use of fair value method for the valuation have opened the opportunity for increased use of professional valuation services. The development of the professional valuers' profession is time consuming, but for the economy of a country is a very important process. Currently, in the Republic of Serbia, valuation of real property is conducted by court experts. However, very small number of them registered their specialty in the field of property valuations at the Ministry of Justice of the Republic of Serbia. Also, very few of them have reported the evidence of professional development. In order to gain insight into the frequency and functionality of professional valuers' use for financial reporting purposes, we have conducted a modest survey in the largest cities of the Republic of Serbia and presented the results in this paper.
\end{abstract}

\section{Key words:}

assets valuation,

fair value,

professional valuers.

\section{INTRODUCTION}

One can say that the assets valuation (regardless of its shape) is a very complex process which has its three parts, the first part is science, the second part is its practical implementation and the third part is the art. When a professional valuer wants to form an expert opinion on the value of the asset, he must use all of his expertise and knowledge in the valuation; he must have adequate experience and be well informed about the local market. Assets valuation, primarily real estate but other types of assets as well, such as financial instruments, played an important role in previous global economic crisis. The profession of independent property valuation (it seems that the Great Depression and the possible involvement of the valuation it quickly forgotten) is frequently mentioned as one of the possible reasons for the genesis and intensified negative impact of the recent crisis. Specifically, mortgage loans are considered as the root of the crisis. Namely, they were granted on the basis of the evalued/overvalued property and those loans were later used as a basis for securitization and sale of mortgage backed securities. Once again, the value of those securities was evaluated/overvalued for financial reporting purposes. In this manner, the quality of provided services of property valuation by valuers indirectly affects the quality of financial reporting and the quality of financial statements auditing process, as well. The question is: Is the current role of valuers marginalized in our society and become an instrument of abuse by clients, management of companies and financial institutions? It seems that the answer to the previous question could be found in the level of competence and expertise of valuers themselves, their Code of Ethics and Code of Professional Conduct or the adequacy of their professional education. Having in mind that the comparative market values which present the basis of the valuation are rarely readily available, many appraisers have to provide more "effort" in order to adequately support their assumptions and conclusions in their valuation process [1]. In this way, valuers who are competent and understand the basic principles of valuation could be discerned from those who simply either ignore or neglect the current situation in the market. Aforementioned implications could be very difficult to isolate or quantify. Based on the aforementioned, we have structured the paper as follows: first, we will explain how the development of the profession of independent property valuers could be improved in the Republic of Serbia. Afterwards, we will call attention to the different purposes of property valuation reports implementation. Finally, we will present the results of the research that we had conducted in order to determine the frequency and the manner of the use of real estate valuation services in the Republic of Serbia for financial reporting purposes.

\section{THE DEVELOPMENT AND FUNCTIONALITY OF INDEPENTENT ASSETS VALUATION PROFESSION}

As noted above, what is necessary for the development of high-quality professional valuation is the adequate education of valuers. Namely, they usually spend too much time in planning and organizing their work, because valuations are usually urgent and are therefore very demanding in regards of organization. Data collection and analysis is very time-consuming, so usually little attention is devoted to the attending conferences at the professional level. University education in valuation has the advantage of understanding the basic principles and concepts of valuation, which can be useful when it comes to introducing new methods of valuation or new types of assets. However, what is lacking in university education is a direct and practical application of the valuation methods and only experts in this field can offer practical courses and this type of education. This problem arose in the late sixties in the USA, when they tried to reconcile these two seemingly opposing sides [2]. Today USA has a highly developed profession of independent valuers.

In fact, as we have already mentioned after the Great Depression it was noticed that qualifications of valuers must be at a higher level; therefore the universities in the United States offered more courses on the assets valuation. A decade later, experts from the practice took over the main role in valuers education [3]. However, the gap between university education and practical courses could be exceeded by engaging experts, valuers with the best reputation and prestige. On the other hand, the 
founding of the professional association, which regulates and promotes this profession, has proved to be essential for the continued development of the profession and valuers' discipline. Professional associations provided additional education in the field of valuation and they provided materials necessary for continuing education by organizing seminars, conferences, professional discussion and by hosting distinguished experts from abroad. In this manner, there is an exchange of knowledge and experience between native and foreign valuers. Also, through professional associations, their member can acquire some of the internationally renowned certificates, which confirm the quality of services provided and commitment to the profession. The variety of the use of assets valuation services is wide indeed; therefore we will list only those that are most commonly associated with this profession.

First of all, accurate property valuation is the basis for any loan which is based on the assessed value of the property. Borrowers count on the maximization of the amount of the loan that will be granted, while lenders hope that estimated value of the property will be sufficient as collateral, in case such need occurs. The relationship between the client and the valuer is indeed complicated and could be a topic for a separate study. Aforementioned is particularly true in the situations when bank client hires the valuer for the evaluation service. Namely, the bank client pays the service, whereas the accountability of valuer is directed towards the bank which grants the loan.

The importance of the profession of independent property valuation is reflected in the process of property tax calculations, as well. However, the property tax for natural persons and property tax for legal entities should be observed as a separate terms. Since 01.01 .2014 , the municipality in which the property is located is in charge for the basic inputs for property tax calculation for physical persons in the Republic of Serbia. Specifically, the municipality provides the "average value" of a property, while the tax authorities multiply that amount with the surface of the property and therefore calculates depreciation, which is greatly reduced and restricted by the lower limit. For legal entities, there are two options: tax calculation based on the established "average" price determined by the municipality, or opting for the assets' carrying amounts in financial reporting (fair value determined by professional valuer). Based on the elected value, they pay $0.4 \%$ of the value as the property tax. Specifically, in determining the tax base of property tax, the estimated market value is usually used, whereas the purchase value of the property is used very rarely. In developed economic systems, and in the Republic of Serbia since 2013, the fair values of properties used for financial reporting purposes, could be a tax base for calculation of property tax [4]. Aforementioned refers to the legal entities which for financial reporting valued properties at fair value (they use revaluation or fair value method).

In situations where there is a decrease in the market values of the real estates, as had already happened in the US in the 1980s and, more recently, in 2009, the fair values follow this trend. However, having in mind that fair values are updated annually for financial reporting purposes (in the Republic of Serbia), for a several periods their value in will be overestimated, therefore the calculated tax will be overestimated, as well. In such situations, valuers must rely almost entirely on their intuition, because the inputs they use are usually the second level information (especially in Serbia). Therefore, additional education and mentorship by professional associations have great significance.

Finally, last but not the least, an important way to use services of professional valuers, is the valuation for financial reporting purposes. Several International Accounting Standards (IAS) impose the use of fair value method for the asset valuation of the legal entity. Among the rest, those are IAS 16 - Property, Plant and Equipment, IAS 40 - Investment Property, IAS 38 - Intan- gible Assets, IAS 39 - Recognition and measurement of financial instruments and IAS 41 - Agriculture. Although neither of the above standards explicitly requires hiring the independent professional valuer, nevertheless they do suggest it. It is presumed that accountants do not have enough experience to assess the value, they usually do not have reliable data base comprising the current market values, and do not have sufficient information about the characteristics of different types of assets, which is to be expected. Please note that in accordance with International Standard on Auditing 620 - Using the work of the auditor's expert, the external auditor has the right to hire the experts, as example professional valuer, in order to validate the assessed values shown in the audited financial statements [5] .

\section{RESEARCH METHODOLOGY AND RESULTS}

In order to find out how frequently professional valuers' service are used, we conducted a brief survey. The research had been conducted in the period from August to mid-October, 2014. The primary method of data collection was an anonymous survey with general questions and those related to the assets valuation for the purposes of financial reporting. Questionnaires were distributed to the accountants who are either employed in bookkeeping agencies or do financial reporting in different legal entities. Several respondents are even owners of bookkeeping agencies. The survey was distributed in the territory of the largest cities in the Republic of Serbia: Belgrade, Novi Sad, Nis and Valjevo. Out of total questionnaires sent to 259 e-mail addresses, we have received 38 completed surveys. However, four surveys (out of 38) were not included in the analysis results, because the respondents gave incomplete answers to the questions, therefore, these responses did not seem relevant to the research and were excluded. Therefore, there were 34 properly filled questionnaires, which makes response rate of $13.1 \%$ of the total sample. The above response rate is considered to be solid for this type of questionnaire, and yet there is a high probability that the results of the study would be completely different if the response rate was higher. Therefore, all the conclusions that we derive in this paper should be used with great caution and more as guidelines, not as rules, bearing in mind that a large number of accountants did not want to answer the survey. On the other hand, submitted questionnaires give the impression of honest replies and opinions. The software solution SPSS (Statistical Package for the Social Sciences) as a statistical program for data processing has been used as an instrument of data processing.

In addition to the basic information related to the respondents' experience in financial reporting, they were asked how often they use the services of a professional valuer in their entity for financial reporting purposes. The results are shown in the first graph.

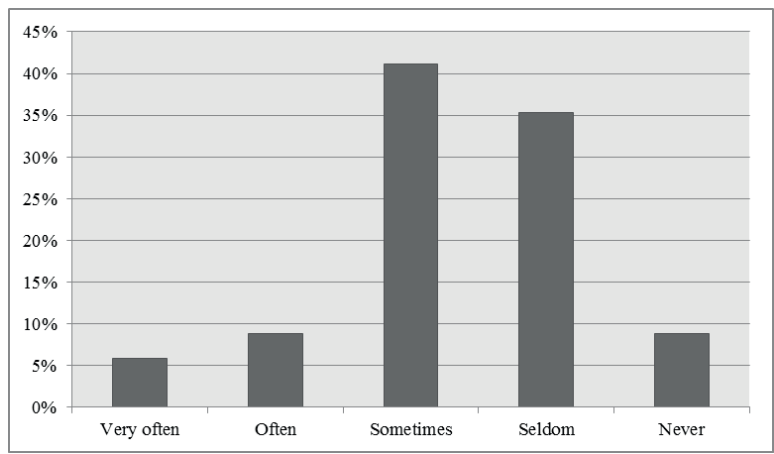

Figure 1. Frequency of professional valuer use for financial accounting purposes 
Further, we were interested in how often respondents use the services of a professional valuer for financial reporting purposes, as well as for which types of assets. Respondents had two options in answering this question, in case they did not use the services of professional valuer. The first option was chosen in the case when respondents have not used the services of a professional valuer so far, because they assessed the value of the assets by themselves. The second option was chosen in the situation when they have not used the professional valuer's services simply because there was no need for valuation. Having in mind second option has not been chosen by any of the respondents we present only the first in the results. On the graph below, we have summarized the answers to this question.

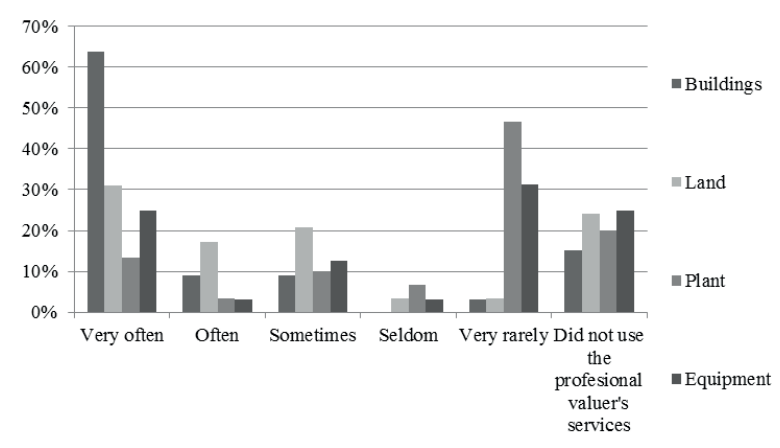

Figure 2. Frequency of professional valuer's use for value assessment of buildings, land, plant and equipment

Finally, we were interested in finding out whether professional valuers perform valuations for financial reporting purposes for groups of assets or individually per asset, as well as how they allocate the estimated values in their reports.

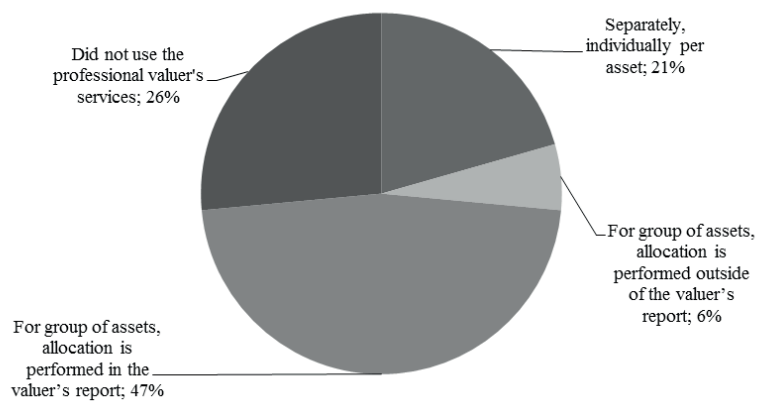

Figure 3. Assets' valuation method used by a professional valuer and allocation of the estimated values in the report

\section{CONCLUDING REMARKS}

Based on the results that we presented in this paper, we can conclude that the profession of independent assets valuation is very important for the economic development of any country. We emphasize that the professional valuer's services for financial reporting in the Republic of Serbia are used seldom, or in rare situations. Aforementioned certainly has impact on the financial reporting quality, having in mind that professional legislation in this area recommends the use of professional valuers' services. In cases where entities use the services of professional valuers, it is usually performed for the purpose of valuation of buildings, land to some extent, while the valuation of plant and equipment is very rarely done. What is commendable is that the results of the study show that in most cases (nearly half) professional valuers perform the assets' valuations for the entire group of assets, which is the correct method in terms of financial reporting requirements. The same valuers perform the allocation of the estimated value per individual assets, which helps in proper execution of bookkeeping activities.

\section{REFERENCES}

[1] E. Strand, D. Browen, \& T. Lesicka, "Real Estate Valuations”, North Western Financial Review, vol. 196, no. 17, 2011, pp. 14-15.

[2] W. Kinnard, "The Approaching Crisis in Appraisal Education”, The Appraisal Journal, vol. 36, no. 2, 1968, pp. 166-174.

[3] A. Woodruff, „Valuation Education for Valuers-Assessors and Appraisers", The Appraisal Journal, vol. 38, no. 2, 1970, pp. 424-438.

[4] Narodna skupština Republike Srbije (2014) „Zakon o porezima na imovinu“, (access: 14/09/2014), [available on site http://www.parlament.gov.rs/akti/doneti-zakoni/donetizakoni.1033.html]

[5] Međunarodna federacija računovođa, (2009) „Međunarodni standard revizije 620 - Korišćenje rezultata rada stručnjaka", (access: 16/09/2014), [available on site www. ifac.org\%2Fsites\%2Fdefault\%2Ffiles\%2Fdownloads\%2 Fa035-2010-iaasb-handbook-isa-620.pdf]

\title{
ZNAČAJ I ZASTUPLJENOST PROFESIONALNIH PROCENITELJA U FINANSIJSKOM IZVEŠTAVANJU
}

\author{
Danijela Ilić ${ }^{1}$, Vule Mizdraković ${ }^{2}$ \\ ${ }^{1}$ Nacionalno udruženje procenitelja Srbije (NUPS), Grčića Milenka 39, Beograd, Srbija, danijela.ilic@procenitelji.org.rs \\ ${ }^{2}$ Poslovni fakultet u Beogradu, Univerzitet Singidunum, Danijelova 32, Beograd, Srbija, vmizdrakovic@singidunum.ac.rs
}

\section{Apstrakt:}

U ovom radu ukazali smo na značaj koji procena vrednosti imovine od strane profesionalnih nezavisnih procenitelja može imati u savremenom poslovanju pravnih lica, pre svega u procesu finansijskog izveštavanja. Uvođenjem zakonske obaveze primene Međunarodnih standarda finansijskog izveštavanja u Republici Srbiji i frekventnijom upotrebom fer vrednosti za vrednovanje imovine, otvorila se prilika za učestalijom upotrebom usluga profesionalne procene vrednosti. Razvoj profesije procenitelja je dugotrajan, ali za privredu jedne države veoma važan proces. Danas, u Republici Srbiji, procenu nepokretne imovine vrše sudski veštaci građevinske struke, pri čemu je veoma mali broj njih prijavio u Ministarstvu pravde užu specijalnost iz oblasti procene nekretnina, uz odgovarajuće dokaze o stručnom usavršavanju. Kako bismo stekli uvid u učestalost i funkcionalnost korišćenja usluga nezavisnih profesionalnih procenitelja, za potrebe finansijskog izveštavanja, sproveli smo istraživanje u najvećim gradovima Republike Srbije i rezultate prikazali u ovom radu.

\section{Ključne reči:}

procena vrednosti imovine, fer vrednost, procenitelji. 